\title{
THE FURNAS/PONTA GROSSA CONTACT AND THE AGE OF THE LOWERMOST PONTA GROSSA FORMATION IN THE APUCARANA SUB-BASIN (PARANÁ BASIN, BRAZIL): INTEGRATED PALYNOLOGICAL AGE DETERMINATION
}

\author{
YNGVE GRAHN, PAULA MENDLOWICZ MAULLER \\ Faculdade de Geologia, UERJ, Rua São Francisco Xavier, 524, 20550-013, Rio de Janeiro, RJ, Brasil. \\ yngvegrahn@gmail.com,mendlowicz@gmail.com \\ PIERREBREUER
}

Geological Technical Services Division, Saudi Aramco, 31311, Dhahran, Saudi Arabia.pierre.breuer@aramco.com

ELVIO PINTO BOSETTI

Laboratório de Paleontologia, UEPG, Rua Otaviano Macedo Ribas, 164, 84070-540, Ponta Grossa, PR, Brasil. elvio.bosetti@pq.cnpq.br

SÉRGIO BERGAMASCHI \& EGBERTO PEREIRA

Faculdade de Geologia, UERJ, Rua São Francisco Xavier, 524, 20550-013, Rio de Janeiro, RJ, Brasil. sergiobe@uerj.br,egberto@uerj.br

\begin{abstract}
The Furnas/Ponta Grossa Formation contact was until recently considered gradational or abrupt and of a Lochkovian to Pragian age in the Apucarana Sub-basin (Paraná Basin, south Brazil). Based on sedimentology and palynomorph evidence a hiatus has been revealed between the Furnas Formation and the overlying Ponta Grossa Formation. The boundary between the topmost Furnas sandstones and the lowermost Ponta Grossa fine-grained sandstones constitutes a transgressive ravinement surface generated during a latest Pragian - early Emsian transgression. The hiatus corresponds to a maximum of ca. 4 Ma. A similar gap is also present in the Alto Garças Sub-basin.
\end{abstract}

Key words: Furnas/Ponta Grossa contact, palynology, Early Devonian, Paraná Basin.

RESUMO - O contato entre as formações Furnas e Ponta Grossa na Sub-bacia de Apucarana (bacia do Paraná, sul do Brasil) foi considerado até recentemente como gradacional ou abrupto e de idade Lockoviana/Praguiana. Com base em evidências sedimentológicas e palinológicas um hiato foi revelado entre a Formação Furnas e a sobrejacente Formação Ponta Grossa. O limite entre os arenitos da porção superior da Formação Furnas e os folhelhos e arenitos finos basais da Formação Ponta Grossa constitui uma superfície de ravinamento gerada na transgressão entre o final do Praguiano e o Eo-Emsiano. O hiato observado envolve um máximo de 4 Ma. Uma lacuna similar também foi descrita na Sub-bacia de Alto Garças.

Palavras-chave: contato Furnas/Ponta Grossa, Palinologia, Eodevoniano, bacia do Paraná.

\section{INTRODUCTION}

Outcrops with a continuous sedimentary record over the Furnas/Ponta Grossa (or Ponta Grossa equivalents) contact are known from many localities in the Paraná Basin (Figures 1-2; for references see Grahn et al., 2000, 2010; Pereira, 2000; Mauller et al., 2009). Published information of lithologies is also known from several Petrobras wells (e.g. Lange, 1967; Bergamaschi, 1999; Grahn et al., 2000, 2010; Bergamaschi \& Pereira, 2001; Gaugris \& Grahn, 2006). Most of these localities display an arenaceous or silty facies in the lowermost part of the Ponta Grossa Formation in the Apucarana Sub-basin. Petri (1948) and Sanford \& Lange (1960) considered these beds to be transitional to the Ponta Grossa Formation. Based on spores, Dino \& Rodrigues (1995) dated early land plants in the upper Furnas Formation (included in the transitional beds by Petri, 1948) at PISA (Figure 2) to be of Pragian age, and the overlying Ponta Grossa Formation to be of Emsian age. Spores identified by Steemans from PISA during the 1990s was partially published by Gerrienne et al. (2001). The same samples, complemented by new ones, were used to review the age previously assigned, which was considered 
as early Lochkovian (Gerrienne et al., 2001). The lithostratigraphic lateral equivalent level at Jackson de Figueiredo (Figure 2), ca. $11 \mathrm{~km}$ west of the PISA locality, is probably coeval of the PISA locality. However, no spores have been found at this locality (Gerrienne et al., 2001). Loboziak et al. (1995), based on spores in the uppermost
Furnas Formation ( $c a .8 \mathrm{~m}$ below the Furnas/Ponta Grossa contact) from core 23 in the Petrobras 2-CN-1-SC well (Figure 2), regarded the Furnas/Ponta Grossa contact as early Pragian. Loboziak \& Melo (2002, p. 141-142) pointed out that the miospores from core 23 in well 2-CN-1-SC (Figure 7) are comparable to those of the lowermost Jatapu and uppermost

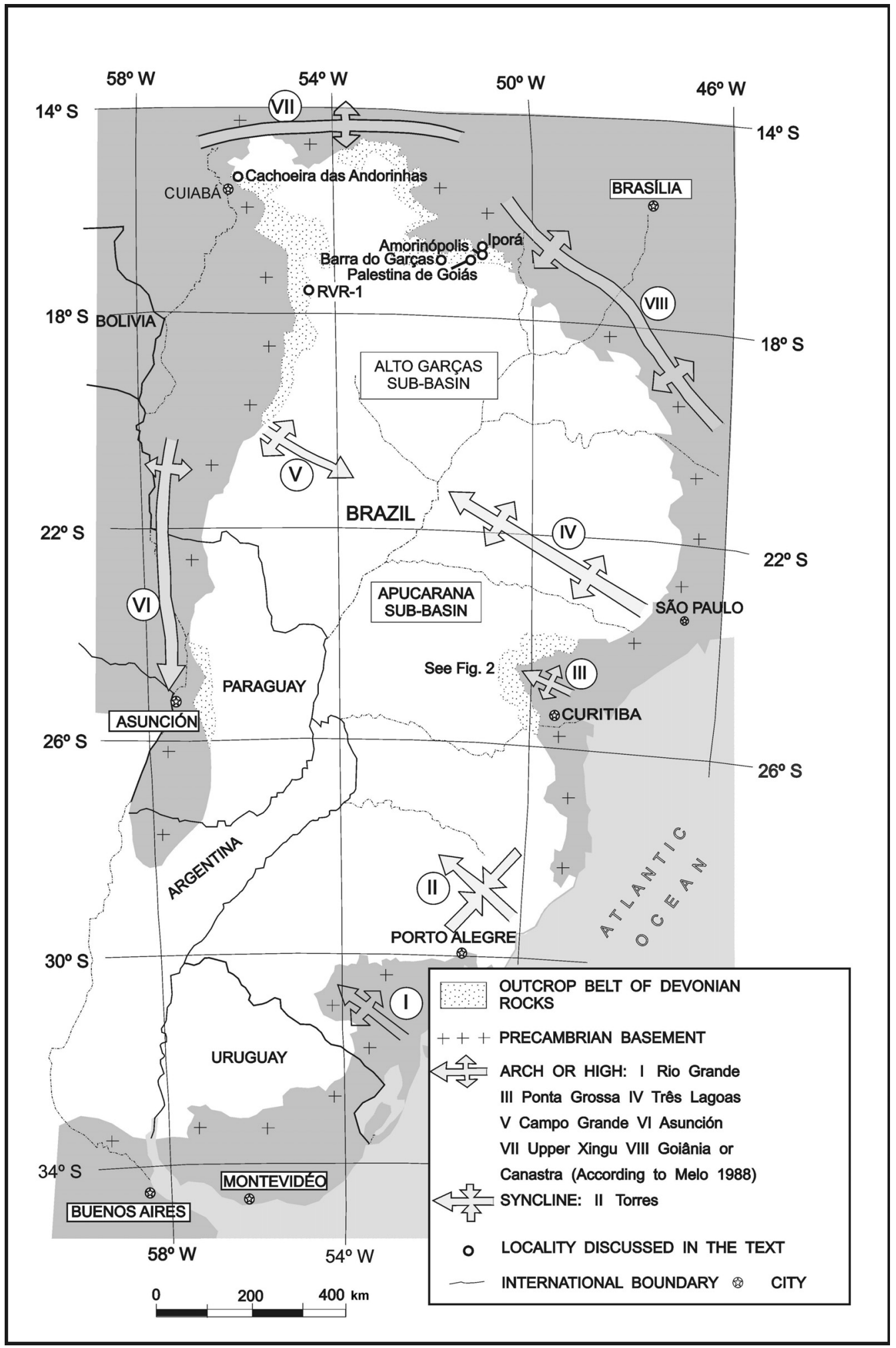

Figure 1. Location map of the localities from the Alto Garças Sub-basin discussed in this study. 
Manacapuru formations in the Amazonas Basin. Both intervals are late Lochkovian as dated by chitinozoans (Grahn, 2005a,b). Lithostratigraphic lateral unit in the Solimões Basin (uppermost Jutaí Fm.) was dated as late Lochkovian (Z Phylozone of the BZ Oppel Zone and Urochitina loboi chitinozoan Sub-zone) by acritarchs and miospores (Rubinstein et al., 2005, 2008) and chitinozoans (Grahn \& Melo, 2003).
The early land plant bearing beds in the uppermost Furnas Formation at the PISA locality are slightly older (Si Phylozone of the MN Oppel Zone; Rubinstein et al., 2005) and of late but not latest Lochkovian age. Dino (1999), Mauller et al. (2009) and Grahn et al.(2010) considered the lower Ponta Grossa Formation as latest Pragian-early Emsian, but the lowermost $10 \mathrm{~m}$ of the Ponta Grossa shales and the Ponta Grossa sandstones below were not sampled
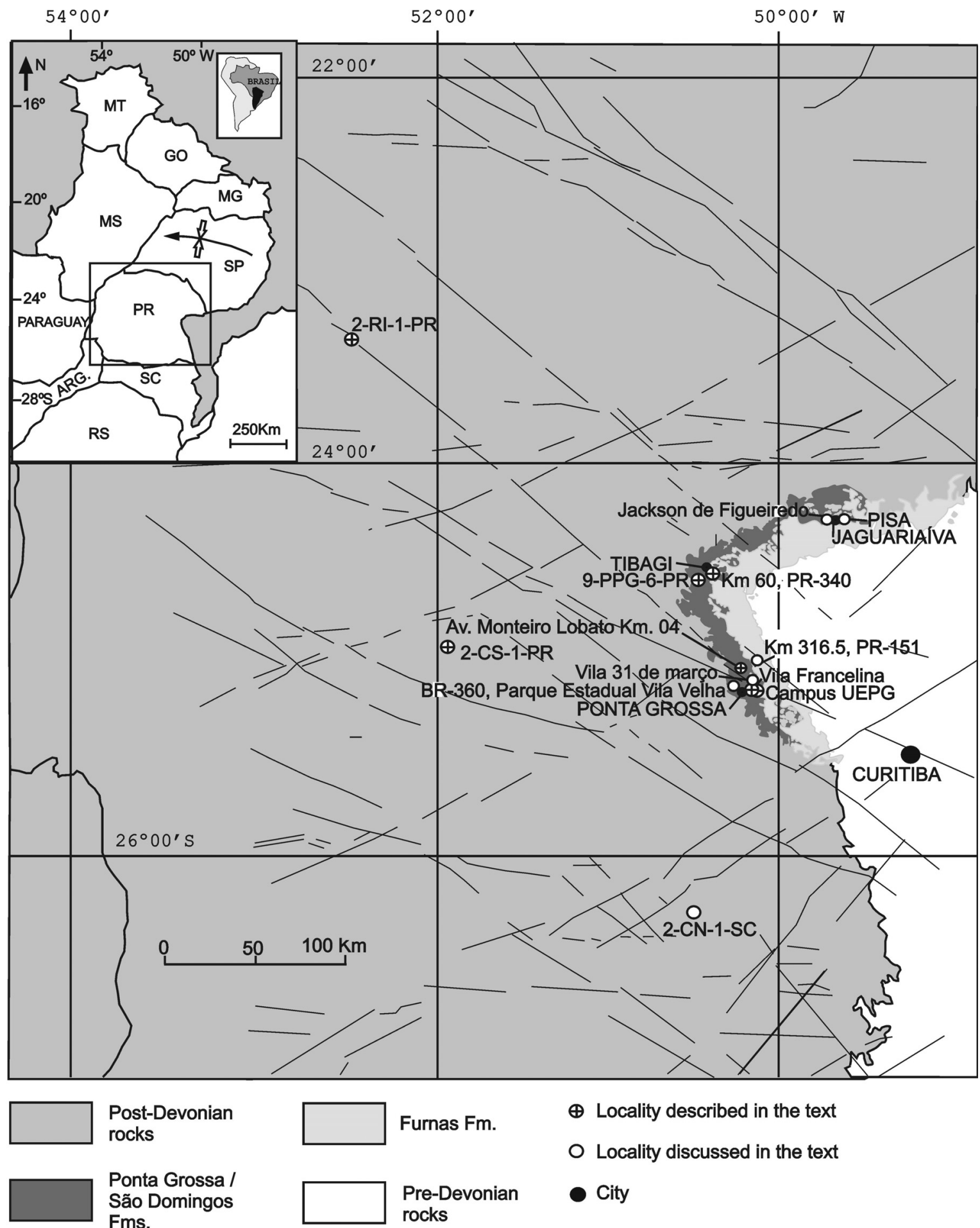

Post-Devonian rocks

\section{Ponta Grossa / São Domingos} Fms.
Furnas Fm.

$\oplus$ Locality described in the text

Locality discussed in the text

Pre-Devonian City rocks

Figure 2. Location map of the localities from the Apucarana Sub-basin discussed and/or investigated in this study. 
or provided no palynological results. The first body fossils from the Ponta Grossa shales in the Apucarana Sub-basin, described in the literature, are from a level 10-15 $\mathrm{m}$ above the contact with the arenaceous beds in the lowermost Ponta Grossa Formation. These fossils are of late Pragian-early Emsian age as evidenced by palynomorphs (Mauller et al., 2009). The base of the Ponta Grossa Formation remains undated. About $2.7 \mathrm{~km}$ north of Amorinópolis city (Figure 1) in the northeastern part of the Alto Garças Sub-basin, chitinozoans have been described from a level $c a$. $1 \mathrm{~m}$ above a conglomerate between the Furnas and Ponta Grossa (= Chapada Group unit 2 sensu Grahn et al., 2010) equivalents (Grahn et al., 2000, 2010). This is in agreement with the lowermost Chapada Group unit 2 in well RVR-1 (Figure 1; Mauller et al., 2009), where a sample ca. $4 \mathrm{~m}$ above the contact with the Furnas Formation (= Chapada Group unit 1 sensu Grahn et al., 2010) is latest Pragian-early Emsian (Mauller et al., 2009; Grahn et al., 2010). At Amorinópolis the plantbearing layers occur 4-5 m below the conglomerate in a deltaic/ lagoonal environment (Quadros \& Melo, 1986; Pereira, 2000). The plant remains are fragmented and probably transported. Other localities with uppermost Furnas Formation in the Alto Garças Sub-basin occur between Iporá and Palestina de Goiás, close to the Caiapó River, and at Barra do Garças (Figure 1; Pereira, 2000). Plant-bearing beds are also known ca. 6-12 m below typical Ponta Grossa shales in a hummocky cross stratified fine-grained sandstone associated with Skolithos at Cachoeira das Andorinhas in the Parque Nacional da Chapada dos Guimarães near Chapada dos Guimarães (Figure 1). The contact with the Furnas sandstones is a ravinement surface, and between the lowermost Ponta Grossa sandstones and the Ponta Grossa shales at this locality there is an interval, ca. $4 \mathrm{~m}$ thick, with fine-grained sandstone with hummocky cross stratification (Pereira, 2000). The preservation of the plant remains suggests transport from continental or transitional beds.

\section{LOCALITIES AND PALYNOLOGICAL RESULTS}

A more argillaceous facies, suitable for palynomorph preservation, is known from four outcrops in the Campos Gerais region (Vila Francelina, Campus UEPG, Avenida Monteiro Lobato km 04 (CEFET), and km 60 on road PR-340) in the Apucarana Sub-basin, and from some wells (e.g. 2-CS1-PR, 2-RI-1-PR and 9-PPG-6-PR) in the same sub-basin. Some of the samples from these localities have yielded spores and acritarchs, and allow dating of the base of the Ponta Grossa Formation, and the initial Early Devonian transgression represented by Ponta Grossa sandstones. The localities are described below. The palynomorphs identified are listed in the Appendix 1.

\section{Vila Francelina $\left(25^{\circ} 04^{\prime} 55^{\prime \prime} \mathrm{S}, 50^{\circ} 06^{\prime} 54^{\prime \prime} \mathrm{W}\right)$}

The Furnas/Ponta Grossa contact does not crop out at this locality (Figures 2, 4), and the closest exposure with
Furnas sandstone is $c a .120 \mathrm{~m}$ north-northeast of the outcropping of lowermost Ponta Grossa shales (Bosetti et al., 2006, 2009; Myszynski Jr. \& Bosetti, 2006; Zabini et al., 2010). Three outcrops constitute the locality (Francelina 13 ), of which the lower part (Francelina 2) is the section investigated (Bosetti et al., 2009). The lithology of the Furnas Formation is fine-grained sandstones with intercalated siltstone layers (ca. $5 \mathrm{~cm}$ thick). No intervening faults are known. The palynomorphs present are not age-diagnostic (Figure 4).

\section{Campus UEPG $\left(25^{\circ} 05^{\prime} 33\right.$ 'S, 5006'15”W)}

The Furnas/Ponta Grossa contact is not exposed at this locality (Figures 2, 4), but ca. $450 \mathrm{~m}$ towards the east occur Furnas sandstones (Bosetti et al., 2006, 2009; Myszynski Jr. \& Bosetti, 2006; Horodyski et al., 2006; Zabini et al., 2010) with the same lithologies as those near Vila Francelina. None of the palynomorphs present are age-diagnostic (Figure 4).

\section{Av. Monteiro Lobato, km 04, CEFET $\left(25^{\circ} 03^{\prime} 18,67^{\prime \prime} \mathrm{S}, 50\right.$} o08'01,52"W)

A new road-cut near the corner of rua Antônio Saad and Avenida Monteiro Lobato in Ponta Grossa (Figures 2, 4), and about $100 \mathrm{~m}$ from Franco da Rocha (Grahn \& Bosetti, 2010), display a $c a .7 \mathrm{~m}$ thick sequence from the upper Furnas ( $c a .3$ $\mathrm{m}$ ) and lower Ponta Grossa (ca. $4 \mathrm{~m}$ ). The Furnas sandstones have the same lithology as at Vila Francelina and Campus UEPG, and the contact with the Ponta Grossa Formation is distinct. A sample collected immediately above the Furnas/ Ponta Grossa contact yielded no palynomorphs.

\section{PR-340, km 60, Tibagi (2446’04'S, 5009'24”W)}

This is the classical locality with the Furnas/Ponta Grossa contact situated ca. $100 \mathrm{~m}$ from the Tibagi River (Figures 2, 4). The levels with early land plant remains are ca. $6 \mathrm{~m}$ below the Furnas/Ponta Grossa contact (Bigarella et al., 1966; Bergamaschi, 1999). Maack (1951) interpreted the siltitic layers with plant remains as representative of glacially varved layers, while Rodrigues el al. (1988) interpreted the outcrop as a record of the early Devonian transgression. The faciological aspect of the outcrop shows a lagoon and deltaic plain covered by barrier sandstone deposited on a foreshore. The outcrop is deeply weathered, and it has not been possible to extract any palynomorphs from the boundary beds, which are very distinct at this locality (Maack, 1951). Petri (1948) and Rodrigues et al.(1988) regarded the fine-grained sandstones above typical Furnas sandstones as transitional beds between the Furnas and Ponta Grossa formations.

2-CS-1-PR, Chapéu do Sol no. 1 (245ㄱ'49.789'”S, 51 ${ }^{\circ} 58$ '2.940”W)

This well was used by Milani et al.(1994), Bergamaschi (1999) and Bergamaschi \& Pereira (2001) for correlations in the Paraná Basin. The lower Ponta Grossa shale in this well (Figure 3) is dated as late Pragian-early Emsian as indicated 
by chitinozoans. Dictyotriletes sp. cf. $D$. richardsonii $(=D$. favosus in Grahn et al., 2005) is known to occur in the lower Ponta Grossa (Mauller et al., 2009), and in the contemporary upper Jaicós Fm., Parnaíba Basin (Grahn et al., 2005). Ancyrochitina pachycerata first occurs at the PragianEmsian transition in the Paraná Basin (Grahn, 2005a).

2-RI-1-PR, Rio Ivai no. 1 (2319'52.067”S, 52²7’18.436”W)

This well was used for correlations in the Paraná Basin by Assine et al. (1994), Milani et al. (1994), Bergamaschi (1999), Bergamaschi \& Pereira (2001) and Zabini et al. (2010). The lower Ponta Grossa shales yielded Ramochitina magnifica which is in agreement with a late Pragian-early Emsian age.

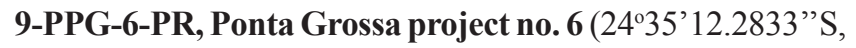
$50^{\circ} 26^{\prime} 10.6697$ 'W)

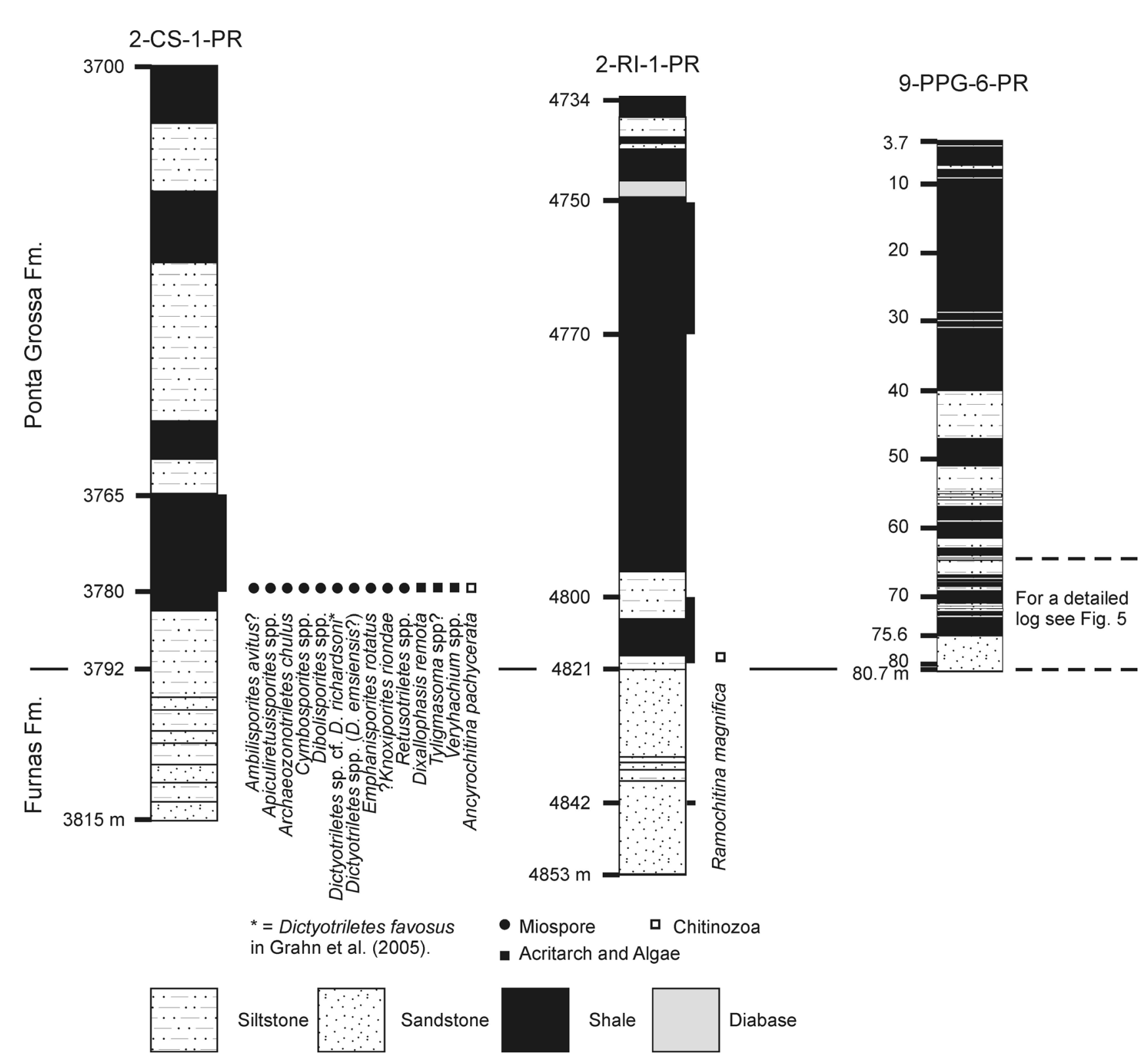

Gaugris \& Grahn (2006) dated the upper part of this core (20-30 m) as pre-late Emsian. Later investigations (e.g. Mauller et al., 2009; Grahn et al., 2010) suggest a late Emsian age for that part of the core, and where Ancyrochitina n. sp. C (pars) sensu Gaugris \& Grahn (2006) is conspecific with Ancyrochitina aff. A. pachycerata (Mauller et al., 2009). The latter species ranges through Emsian strata in the Paraná Basin (Mauller et al., 2009; Grahn et al., 2010). The presence of a diverse Ancyrochitina assemblage including Ancyrochitina pachycerata s.s. characterizes the late Emsian in the Paraná Basin. This age assignment is in agreement with the present results. A low diversity miospore assemblage including Dictyotriletes subgranifer dominates the sequence in the lowermost Ponta Grossa Formation (Figure 5), which is Latest Emsian chitinozoans occur at $68.80 \mathrm{~m}$. Layers with developed as storm bars (Rezende \& Bergamaschi, 2008).

Figure 3. Lithologic column and palynomorph range chart for the wells investigated. 


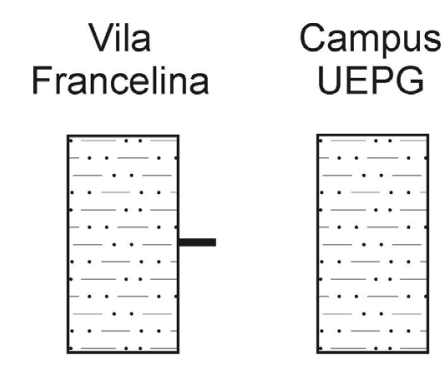

$\mathrm{Km} 60$

PR-340

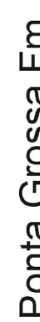

(Tibagi)
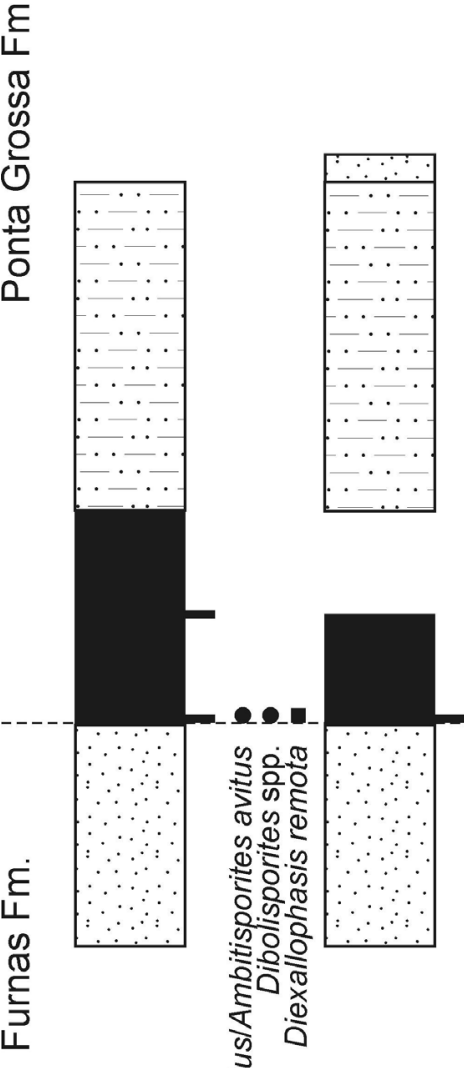

Av. Monteiro Lobato, $\mathrm{Km} 04$ CEFET

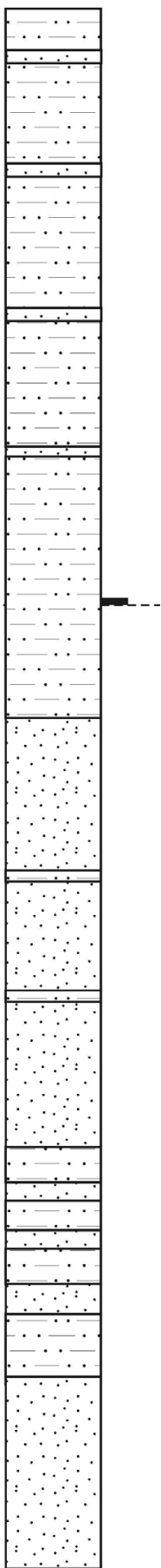

Figure 4. Lithologic column and palynomorph range chart for the outcrops investigated. For legend, see Figure 3. 
reworked material occur at 72.00 and $72.30 \mathrm{~m}$, and the early Emsian (PoW Su spore Zone)/late Emsian (AP spore Zone) boundary is questionable, drawn at $72.30 \mathrm{~m}$ (Figure 5). No positive evidence was found for the Emsian $\mathrm{AB}$ and $\mathrm{FD}$ spore zones.

\section{THE NATURE OF THE FURNAS/PONTA GROSSA CONTACT}

The upper part of the Furnas Formation is characterized by fluvial and coastal coarse sandstones with silty layers intercalated with coarse sandstones. These silty layers may contain plant remains. The base of the Ponta Grossa Formation represents the main transgressive surface into a $2^{\text {nd }}$ order cycle, and a $3^{\text {rd }}$ order boundary (Bergamaschi, 1999). The lithology consists of fine-grained littoral-sublittoral sandstones with Skolithos (Borghi, 1993), sometimes reworked by storms (hummocky cross stratification, storm bars) or by intertidal erosion in more protected parts of the basin (cyclic tidal bars). A cycle is initiated with a hardground and ends with muddy layers. Bioturbation is common and increases upwards in the tidal bar. Up to a maximum $20 \mathrm{~m}$ of lowermost Ponta Grossa displays hummocky cross stratified beds, deposited by oscillatory currents during storms that reworked the sediments on the ravinement surface (Tamura \& Masuda, 2005; Grahn \& Bosetti, 2010). Where hummocky cross stratification, storm bars or intertidal cyclic bars are missing there are low-angle tabular sandstones indicating foreshore deposition.

Petri (1948) and Sanford \& Lange (1960) considered these beds as the upper part of the transitional beds to the overlying more shaly Ponta Grossa Formation. Caster (1952) found evidence for both abrupt and what he considered a gradational contact. Diniz (1985) on the other hand regarded these beds as part of the Ponta Grossa Formation. Bigarella et al. (1966) remarked that the uppermost part of the Furnas Formation has several layers with siltstones, argillaceous and arenaceous siltstones, and argillaceous shaly beds although not similar to those in the Ponta Grossa Formation. These shaly layers always overlay an erosional surface and truncated cross-stratified arenites characteristic of the Furnas Formation. Bergamaschi (1999) and Bergamaschi \& Pereira (2001) interpreted the plant-bearing beds as deltaic-lagoonal with the plants in situ and the arenites as deposited by crevasse-splay flux in a lagoonal area recovered by tabular sandstones associated with foreshore deposits (Rodrigues et al., 1988; Bergamaschi \& Pereira, 2001). Assine (1996) found hummocky cross-stratified arenites associated with lags of aligned disk-shaped pebbles with no excavation structures below. He interpreted these beds as trangressive ravinement surfaces reworked by storm action in a rapid transgression from northeast. Similar beds are known from the lower Emsian in the Paraná Basin (Grahn \& Bosetti, 2010). Assine (1996) and Bergamaschi (1999) recognized a hiatus between the Furnas and Ponta Grossa formations, and placed the upper low angle sandstones below Ponta Grossa shales (transitional beds by Petri, 1948) in the lowermost Ponta Grossa Formation. The uppermost Furnas Formation is characterized by (i) silt layers containing plant remains and rare palynomorphs ( $\mathrm{Mi}-$ lagres et al., 2007), dated as late, but not latest Lochkovian (Loboziak \& Melo, 2002; Rubinstein et al., 2005); and (ii) rare laterally extensive conglomeratic layers with gravel and pebbles. The Furnas Formation shows a general regressive tendency upwards. The early land plant beds are here considered as a late Lochkovian datum plane (Si Phylozone in the MN Oppel Zone; Gerrienne et al., 2001; Rubinstein et al., 2005, 2008). A dense sampling of core 9-PPG-6-PR from the base of the "transitional beds" (76.5 to $80.7 \mathrm{~m}$ ) below typical Ponta Grossa Formation (from 76.5 m upwards; Figures 3,5 ) revealed that these beds are probably late Pragianearly Emsian. Thus, the "transitional beds" are of the same age as the lower part of the typical Ponta Grossa shales. Attempts were made to date samples from lowermost Ponta Grossa Formation with the Rb-Sr-method, but these failed because of the unsuitable lithologies of the samples (Ana Maria Misuzaki, pers. comm., 2009). The lowermost Ponta Grossa sandstones were deposited as a result of an extensive reworking of a ravinement surface that delimits the Furnas Formation. The age of the ravinement surface is not older than latest Lochkovian, and not younger than latest Pragian, when the transgressive Ponta Grossa sandstones were deposited. Early land plant layers have been found at varying depths below the Furnas/Ponta Grossa contact at outcrop localities in the Apucarana Sub-basin (Figure 2): (i) PISA ca. $2 \mathrm{~km}$ east of Jaguariaiva city at approximately $20 \mathrm{~m}$ below the top of the Furnas Formation, which is here truncated by the Carboniferous Itararé Group (Dino \& Rodrigues, 1995; Dino et al., 1995; Mussa et al.,1996; Bergamaschi, 1999; Gerrienne et al., 2001; Rubinstein et al., 2005); (ii) Jackson de Figueiredo $c a$. $11 \mathrm{~km}$ west of the PISA locality. Plant remains occur $c a$. $5 \mathrm{~m}$ below the top of the Furnas Formation (Mussa et al., 1996; Bergamaschi, 1999; Gerrienne et al., 2001); (iii) Carambéi, $\mathrm{km} \mathrm{316.5,} \mathrm{PR-151} \mathrm{at} c a .20 \mathrm{~m}$ below the top of the Furnas Formation (Assine, 1996; Milagres et al., 2007). The contact with Ponta Grossa Formation has not been observed; (iv) km 60, PR-340 (Figure 4) close to Tibagi River (Tibagi city) at $c a$. $6 \mathrm{~m}$ below the top of the Furnas Formation (Bigarella et al., 1966; Bergamaschi, 1999); (v) BR-360, $1 \mathrm{~km}$ west of the entrance to Parque Estadual Vila Velha at 8-10 m below the top of the Furnas Formation (Bigarella et al., 1966). The contact with Ponta Grossa Formation has not been observed; (vi) Vila 31 de março, Ponta Grossa, at $2.5 \mathrm{~m}$ below the top of the Furnas Formation (Rodrigues et al., 1989). The contact with Ponta Grossa Formation has not been observed.

The variable thickness of the basal Ponta Grossa sandstones suggests a surface with a slightly undulating relief when the late Pragian-early Emsian transgression reached the area. The maximum gap between the youngest dated Furnas Formation and the base of the Ponta Grossa 


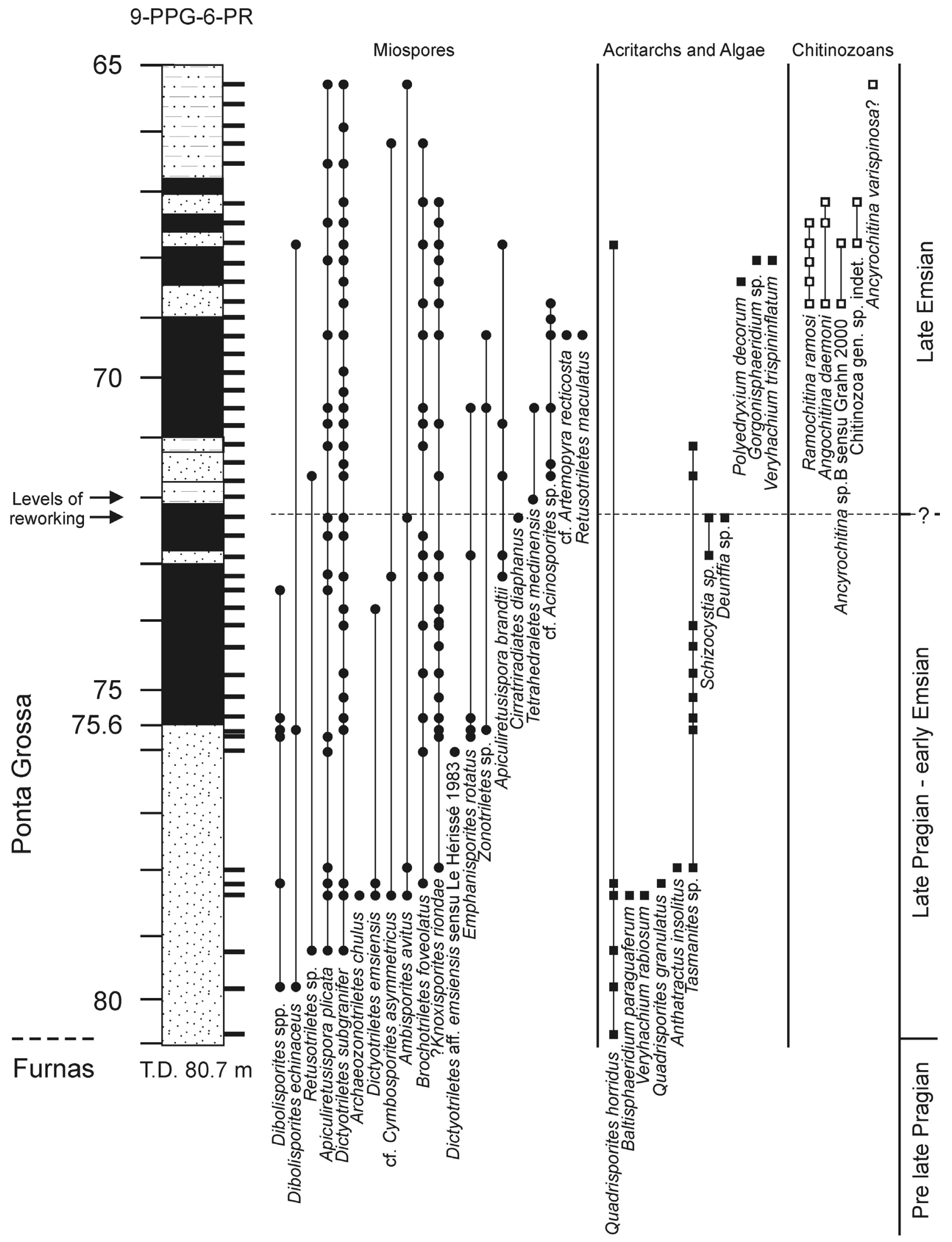

Figure 5. Lithologic column and palynomorph range chart for well 9-PPG-6-PR. For legend, see Figure 3. 
Formation corresponds to the E Phylozone of the BZ Oppel Zone-pre PoW Su spore Zone (latest Lochkovian and most of the Pragian), a time interval representing $c a$. $4 \mathrm{Ma}(\mathrm{Fi}-$ gure 6).

\section{REMARKS ON THE MIOSPORE AND CHITINOZOAN ASSEMBLAGES}

In the Paraná Basin, late Lochkovian spores have been described from the uppermost Furnas Formation. Dino and Rodrigues (1995) and Dino et al.(1995) found Dictyotriletes emsiensis and Dictyotriletes subgranifer at the PISA locality and dated these beds as Pragian. Loboziak et al.(1995) described a miospore assemblage from the uppermost Furnas in well 2-CN-1-SC, and based on the occurrence of Dictyotriletes emsiensis and Dibolisporites cf. eifeliensis, these beds were considered early Pragian. The samples from PISA were re-investigated by Gerrienne et al.(2001), and the specimens of Dictyotriletes emsiensis are now interpreted as intermediate forms between $D$. emsiensis and D. granulatus. These forms are known from the late Lochkovian MN Oppel Zone and younger strata in western Gondwana (D. emsiensis Morphon Assemblage Zone by Rubinstein et al., 2005). The presence of Aneurospora geikiei and Synorisporites verrucatus further strengthen a Lochkovian age for the uppermost Furnas Formation. According to Rubinstein et al.(2005), the absence of characteristic species such as Dibolisporites eifeliensis and Dibolisporites echinaceus at PISA suggests a late, but not latest Lockovian age ( $\mathrm{Si}$ Phylozone of the MN Oppel Zone). The presence of Dibolisporites cf. eifeliensis in core 23 in well 2-CN-1-SC suggests a slightly younger age, but not older than the $\mathrm{Z}$ Phylozone of the BZ Oppel Zone. Core 23 probably has a coeval stratigraphic position with the latest Lochkovian assemblages from the Solimões Basin (Rubinstein et al., 2005). No chitinozoans are known from the Furnas Formation.

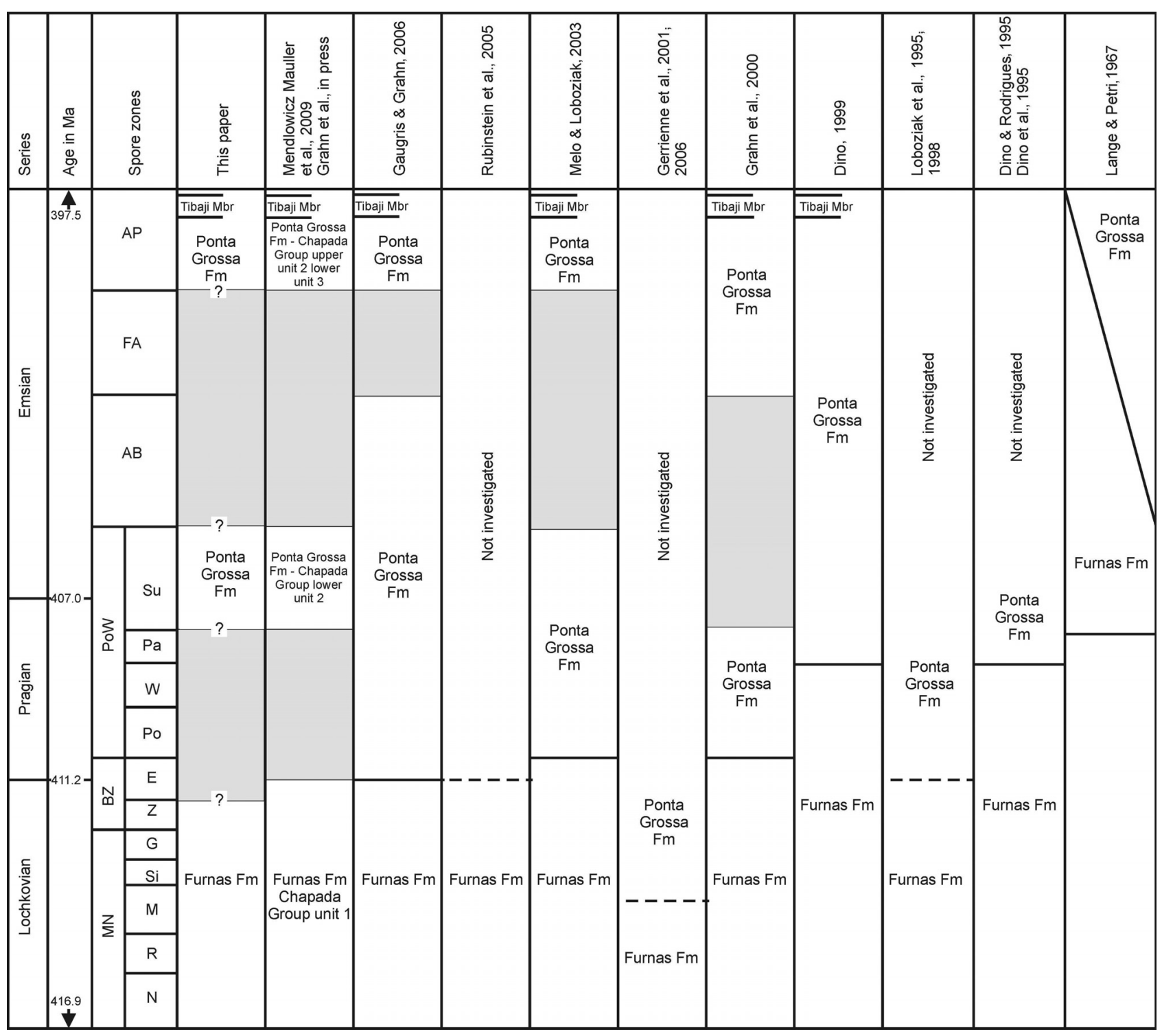

Figure 6. Correlation scheme for the Furnas/Ponta Grossa contact. 


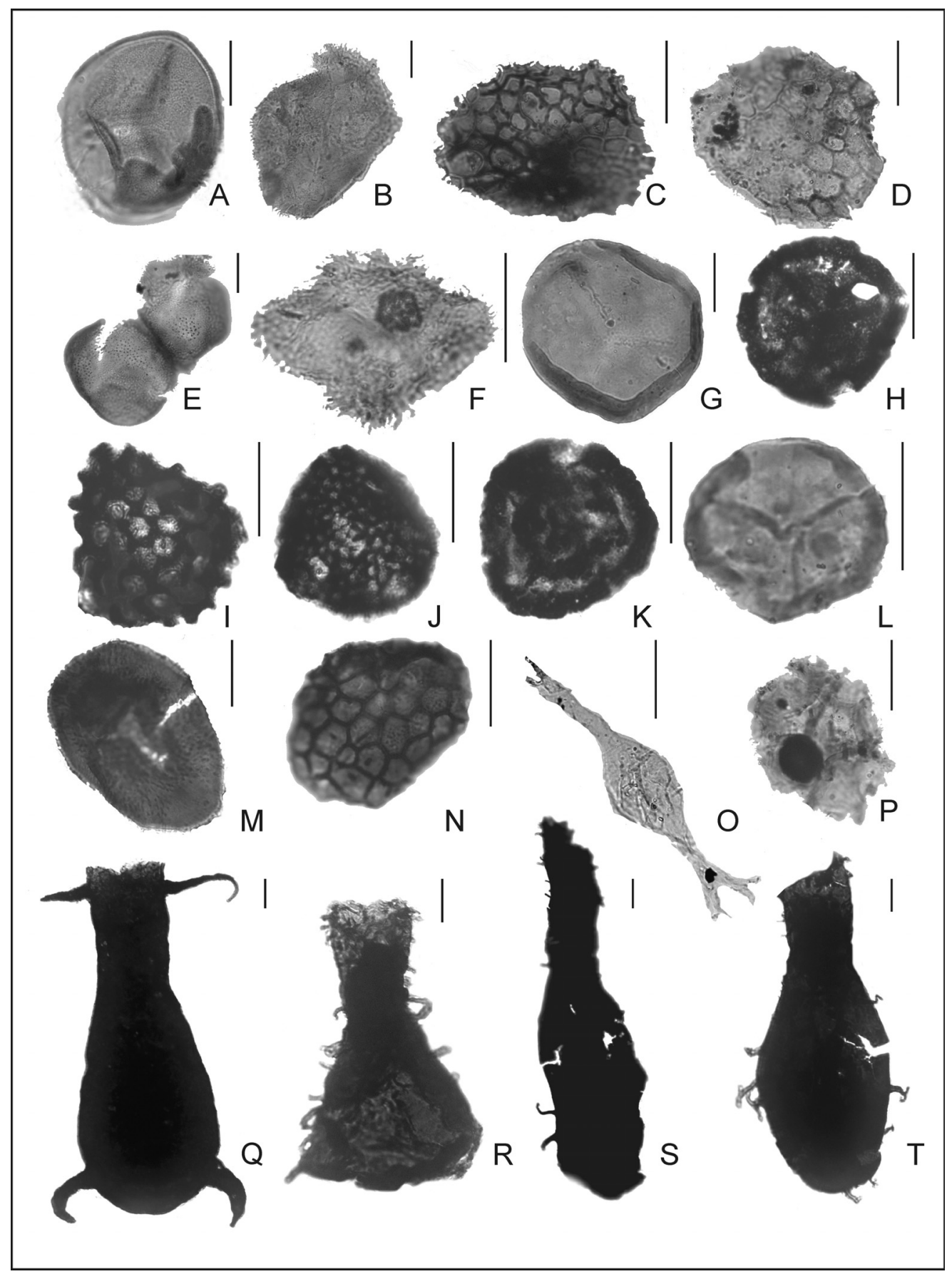

Figure 7. Selected spores (A-G, G-N), algae (F), acritarchs (O-P), and chitinozoans (Q-T) from the Furnas and Ponta Grossa formations in the Apucarana Sub-basin. A, Apiculiretusispora plicata. Well 9-PPG-6-PR, 79.28 m. Ponta Grossa Fm. BPA 200908831, T68/1; B, cf. Cymbosporites asymmetricus. Well 9-PPG-6-PR, 78.42 m. Ponta Grossa Fm. BPA 200908830, F58/4; C,Dictyotriletes aff. emsiensis sensu Le Hérisse 1983. Well 9-PPG-6-PR, 76.00 m. Ponta Grossa Fm. BPA 200908403, P57/4; D, Dictyotriletes subgranifer. Well 9-PPG6-PR, 68.10 m. Ponta Grossa Fm. BPA 200908377, T68/2-4; E, Dibolisporites spp. Well 9-PPG-6-PR, 79.80 m. Ponta Grossa Fm. BPA 200908832, W64/2; F, Quadrisporites horridus. Well 9-PPG-6-PR, 78.42 m. Ponta Grossa Fm. BPA 200908830, U69/1; G, Ambitisporites avitus. Well 9-PPG-6-PR, 78.42 m. Ponta Grossa Fm. BPA 200908830, X45/3; H, Ambitisporites avitus? Well 2-CS-1-PR, 3765-3780 m, Ponta Grossa Fm. BPA 9407124, E17c; I, cf. Brochotriletes foveolatus Well 2-CS-1-PR, 3765-3780 m. Ponta Grossa Fm. BPA 9407124, P14; J, Dictyotriletes sp. cf. D. richardsonii. Well 2-CS-1-PR, 3765-3780 m. Ponta Grossa Fm. BPA 9407124, U17/3; K, ?Knoxisporites riondae. Well 2-CS-1-PR, 3765-3780 m. Ponta Grossa Fm. BPA 9407124, R34/4; L, Synorisporites papillensis. Well 2-CN-1-SC, core 23 (1455-1457 m). Furnas Fm. BPA 2917, O59/3-4; M, Dibolisporites echinaceus. Well 2-CN-1-SC, core 23 (1455-1457 m). Furnas Fm. BPA 12847, K45/ 2; N, Dictyotriletes emsiensis Well 2-CN-1-SC, core 23 (1455-1457 m). Furnas Fm. BPA 12848, N47/4; O. Anthatractus insolithus. Well 9PPG-6-PR, 78.00 m. Ponta Grossa Fm. BPA 200908828, V68/3; P, Polyedrixium decorum. Well 9-PPG-6-PR, 68.40m. Ponta Grossa Fm. BPA 200908378, W70; Q, Ancyrochitina pachycerata. Well 2-CS-1-PR, 3765-3780 m. Ponta Grossa Fm. BPA 9407124, D49c; R, Ancyrochitina sp. B sensu Grahn 2000. Well 9-PPG-6-PR, BPA 200908376, 67.80 m. Ponta Grossa Fm. 200908376, O60/3; S, Ramochitina magnifica. Well 2-RI-1-PR, 4800-4820 m. Ponta Grossa Fm. BPA 9407145, T36c; T, Ramochitina ramosi. Well 9-PPG-6-PR, 68.70m. Ponta Grossa Fm. BPA 200908379, J46c. Scale bars $=20 \mu \mathrm{m}$ 
A poorly diagnostic miospore assemblage occurs from the base of the Ponta Grossa sandstones into the more shaly parts of the formation, suggesting the PoW Su spore Zone. The index species Dictyotriletes subgranifer is common and occurs together with other characteristic species such as Dictyotriletes emsiensis morphon and Dictyotriletes sp. cf. D. richardsonii. Chitinozoans are rare but Ramochitina magnifica and Ancyrochitina pachycerata are present. The late Emsian is pooly characterized by miospores in this study. The chitinozoans constitute a characteristic latest Emsian assemblage with species such as Ancyrochitina sp. B sensu Grahn, 2000, Angochitina daemoni, and Ramochitina ramosi. These species also occur in the Tibagi Member of the Ponta Grossa Formation, as defined in the Tibagi-Telemâco Borba section (Bergamaschi, 1999; Grahn et al., 2000).

\section{CONCLUDING REMARKS}

For the first time the lowermost Ponta Grossa Formation has been dated. An integrated (spore, acritarch and chitinozoan) palynomorph study of the upper Furnas and lower Ponta Grossa formations reveals a hiatus between the ravinement surface that delimits the Furnas and the initial lower Devonian transgression represented by the basal Ponta Grossa sandstones (Figure 6). This gap corresponds to a maximum of $c a .4 \mathrm{Ma}$ (E Phylozone of the MN Oppel Zone and pre-PoW Su spore Zone). The Ponta Grossa basal sandstones (transitional beds sensu Petri, 1948) were deposited through an extensive erosion and reworking of the ravinement surface (hummocky cross stratification, storm bars and intertidal cyclic bars), and are dated as late Pragianearly Emsian (PoW Su spore Zone). The same age is found in the lower Ponta Grossa shales. The finds of early land plants in the uppermost Furnas Formation have been previously dated as late, but not latest Lochkovian (Si Phylozone of the MN Oppel Zone) by Rubinstein et al. (2005, 2008). On the eastern border of the Paraná Basin a ravinement surface can be associated with a $3^{\text {rd }}$ order sequence boundary. Zalan et al. (1987) interpreted the contact between the Ponta Grossa sandstones and shales as a gap corresponding to a maximum of ca. $10 \mathrm{Ma}$. A possible gap within the Ponta Grossa Formation corresponding to the Emsian AB-FD Oppel Zones, and possibly a latest Emsian age for the Tibagi Member s.s., is also suggested by the present study.

\section{ACKNOWLEDGMENTS}

YG thanks the CNPq (PQ 309751/2007-1), which made his work possible through grants. PMM thanks CAPES (BEX 4515/05-6) for grants. PB acknowledges the Saudi Aramco for granting permission to work on this material. EPB thanks the CNPq (PQ 480427/2007-0) for financial support and to the Palaios Group/UEPG/CNPq for support in the field work. SB acknowledges the support of FAPERJ. EP thanks CNPq (304961/2007-8) and FAPERJ for grants supporting his research. Thanks are also due to C.S. Valladares, head of the post-graduate program at the Faculty of Geology at UERJ for access to the facilities, to Project Paleosul at UERJ for granting samples from well 9-PPG-6-PR, and to PETROBRAS for permission to publish this paper. Ana M. Misuzaki is warmly thanked for assessing the potential of some Ponta Grossa Fm. samples for geochronological age determinations, and C.E.S. Cruz for discussions on the sedimentology of well 9PPG-6-PR. Manuscript evaluation by M.E. Longhin and M. Arai are greatly appreciated. Art Boucot checked the English. The comments of the two reviewers, P. Steemans and C. Rubinstein, greatly improved the content. Our sincere thanks go to all.

\section{REFERENCES}

Assine, M.L. 1996. Aspectos da estratigrafia das seqüencias précarboniferas da bacia do Paraná no Brasil. Universidade de São Paulo, Doctoral thesis, 207 p.

Assine, M.L.; Soares, P.C. \& Milani, E.J. 1994. Seqüências tectonosedimentares mesopaleozóicas da bacia do Paraná, sul do Brasil. Revista Brasileira de Geociências, 24:77-89.

Bergamaschi, S. 1999. Análise estratigráfica do Siluro-Devoniano (formações Furnas e Ponta Grossa) da sub-bacia de Apucarana, bacia do Paraná, Brasil. Universidade de São Paulo, Doctoral thesis, $167 \mathrm{p}$.

Bergamaschi, S. \& Pereira, E. 2001. Caracterização de seqüências deposicionais de $3^{\mathrm{a}}$ ordem para o Siluro-Devoniano na subbacia de Apucarana, bacia do Paraná, Brasil. Ciência,Técnica, Petróleo, 20:63-72.

Bigarella, J.J.; Salamuni, R. \& Marques Filho, P.L. 1966. Estruturas e texturas da Formação Furnas e sua significação paleogeográfica. Boletim da Universidade Federal do Paraná. Geologia, 18:1-119.

Borghi, L. 1993. Caracterização e análise faciológica da Formação Furnas (Pridoli-Eodevoniano) em afloramentos do flanco sul do arco estrutural de Ponta Grossa, borda leste da bacia do Paraná, Estado do Paraná, Brasil. Universidade Federal do Rio de Janeiro, M. Sc. thesis, 227 p.

Bosetti, E.P.; HorodyskiI, R.S. \& Myszynski Jr., L.J. 2006. Diagnóstico de seções estratigráficas de superfície do corredor de rochas devonianas do bairro de Uvaranas em Ponta Grossa, PR: seções Francelina I, II, III e Campus UEPG. Boletim Paleontologia em Destaque, 53:22-23.

Bosetti, E.P.; Godoy, L.C.; HorodyskiI, R. S.; Myszynski Jr, L.J. \& Zabini, C. 2009. Interpretação paleoambiental na sequência basal da formação Ponta Grossa (Devoniano) do município de Ponta Grossa, Paraná, Brasil. Terr@Plural,3:137-156.

Caster, K.E. 1952. Stratigraphic and paleontologic data relevant to the problem of the afro-american ligation during the Paleozoic and Mesozoic. Bulletin of the American Museum of Natural History, 99:105-152.

Diniz, M.N. 1985. Interpretação ambiental da Formação Ponta Grossa na parte central da Bacia do Paraná: um estudo de subsuperficie. Universidade de São Paulo, M. Sc. thesis, 148 p.

Dino, R. 1999. Palynostratigraphy of the Silurian and Devonian sequence of the Paraná Basin, Brazil. In: ORDOVICIAN/ DEVONIAN PALYNOSTRATIGRAPHY IN WESTERN GONDWANA: UPDATE, PROBLEMS AND 
PERSPECTIVES, 1, 1999. Resumos expandidos, Rio de Janeiro, UERJ, p. 27-61.

Dino, R. \& Rodrigues, M.A.C. 1995. Palinomorfos eodevonianos da Formação Furnas, bacia do Paraná. Anais da Academia Brasileira de Ciências, 67:107-116.

Dino, R.; Bergamaschi, S.; Pereira, E.; Melo, J.H.G.; Loboziak, S. \& Steemans, P. 1995. Biochronostratigraphic investigations of the Pragian and Emsian stages on the southeastern border of the Paraná Basin. In: SIMPÓSIO SOBRE CRONOESTRATIGRAFIA DA BACIA DO PARANÁ, 2, 1995. Resumos expandidos, Porto Alegre, UFRGS, p. 1925.

Gaugris, K.A. \& Grahn, Y. 2006. New chitinozoan species from the Devonian of the Paraná basin, south Brazil, and their biostratigraphic significance. Ameghiniana, 43:293-310.

Gerrienne, P.; Bergamaschi, S.; Pereira, E.; Rodrigues, M.A.C. \& Steemans, P. 2001. An early Devonian flora, including Cooksonia from the Paraná Basin (Brazil). Review of Palaeobotany and Palynology, 116:19-38.

Grahn, Y. 2005a. Devonian chitinozoan biozones of Western Gondwana. Acta Geologica Polonica, 55:211-227.

Grahn, Y. 2005b. Silurian and Lower Devonian chitinozoan biostratigraphy of the Trombetas Group, Amazonas Basin, northern Brazil. Bulletin of Geosciences, 80:245-276.

Grahn, Y. \& Melo, J.H.G. 2003. Silurian-Devonian chitinozoan biostratigraphy along the Urubu, Uatumã and Abacate rivers in the western part of the Amazonas Basin, northern Brazil. Bulletin of Geosciences, 78:373-391.

Grahn, Y. \& Bosetti, E.P. 2010. Storm deposited pebble and cobblesized particles in the early Emsian of the Ponta Grossa Formation, Paraná Basin (State of Paraná, Brazil). Revista Brasileira de Geociências, in press.

Grahn, Y., Pereira, E. \& Bergamaschi, S. 2000. Silurian and Lower Devonian chitinozoan biostratigraphy of the Paraná Basin in Brazil and Paraguay. Palynology, 24:143-172.

Grahn, Y.; Melo, J.H.G. \& Steemans, P. 2005. Integrated chitinozoan and miospore zonation of the Serra Grande Group (Silurianlower Devonian), Parnaíba Basin, northeast Brazil. Revista Española de Micropaleontología, 37:183-204.

Grahn, Y.; Mauller, P.M.; Pereira, E. \& Loboziak, S. 2010. Palynostratigraphy of the Chapada Group and its significance in the Devonian stratigraphy of the Paraná Basin, south Brazil. Journal of South American Earth Sciences, 29:354-370.

Horodyski, R.S.; Bosetti, E. \& Myszynski Jr., L.J. 2006. Tafonomia de alta resolução do afloramento do campus UEPG, sucessão devoniana, sub-bacia de apucarana, bacia do Paraná, Brasil. In: ENCONTRO ANUAL DE INICIAÇÃO CIENTÍFICA, 15/ ENCONTRO DE PESQUISA DA UEPG, 6, 2006. Boletim de resumos, Ponta Grossa, UEPG, p. 1.

Lange, F.W. 1967. Biostratigraphic subdivision and correlation of the Devonian in the Paraná Basin. Boletim Paranaense de Geociencias, 21/22:63-98.

Le Hérissé, A. 1983. Les spores du Dévonien inférieur du Synclinorium de Laval (MassifArmoricain). Palaeontographica $B$, 188:1-81.

Loboziak, S. \& Melo, J.H.G. 2002. Devonian miospore successions of Western Gondwana: update and correlation with South Euramerican miospore zones. Review of Palaeobotany and Palynology, 121:133-148.
Loboziak, S.; Melo, J.H.G.; Steemans, P. \& Barrilari, I.M.R. 1995. Miospore evidence for pre-Emsian and latest Famennian sedimentation in the Devonian of the Paraná Basin, south Brazil. Anais da Academia Brasileira de Ciências, 67:391-392.

Maack, R. 1951. Vestígios pré-devonianos de glaciação e a seqüência das camadas devonianas do Estado do Paraná. Arquivos de Biologia e Tecnologia, 6:197-230.

Mauller, P.M.; Grahn, Y. \& Cardoso, T.R.M. 2009. Palynostratigraphy from the lower Devonian of the Paraná Basin, south Brazil, and a revision of contemporary chitinozoan biozones from Western Gondwana. Stratigraphy, 6:313-332.

Milagres, I.M.; Pereira, E.; Bergamaschi, S.; Rodrigues, M. A. C. \& Gerrienne, P. 2007. O registro da tafoflora devoniana observada no arco de Ponta Grossa, bacia do Paraná, e suas implicações paleogeográficas. In: I.S. Carvalho \& R.C. Tardín (eds.) Paleontologia, Cenários de Vida. 1 ed. Editora Interciência, v. 1, p. 25-48.

Milani E. J.; França A.B. \& Schneider R.L. 1994. Bacia do Paraná. Boletim de Geociências da Petrobrás, 8:69-82.

Mussa, D.; Borghi, L.; Bergamaschi, S.; Schubert, G.; Pereira, E. \& Rodrigues, M.A.C. 1996. Estudo preliminar da tafoflora da Formação Furnas, bacia do Paraná, Brasil. Anais da Academia Brasileira Ciências, 68:65-89.

Myszynski, L.J. \& Bosetti, E. 2006. Corredor de afloramentos da sucessão devoniana (?Lockoviano-Frasniano) do bairro de Uvaras, Ponta Grossa, Paraná, Brasil. In: ENCONTRO ANUAL DE INICIAÇÃO CIENTÍFICA, 15, 2006. Boletim de resumos, Ponta Grossa, UEPG, p. 1.

Pereira, E. 2000. Evolução tectono-sedimentar do intervalo Ordoviciano-Devoniano da bacia do Paraná com ênfase na sub-bacia de Alto Garças e no Paraguai Oriental. Universidade de São Paulo, Doctoral thesis, 277 p.

Petri, S. 1948. Contribuição ao estudo do Devoniano paranaense. Rio de Janeiro, Departamento Nacional da Produção Mineral, Divisão de Geologia e Mineralogia, 125 p. (Boletim 129).

Quadros, L.P. \& Melo, J.H.G. 1986. Ocorrência de restos vegetais em sedimentos continentais do Paleozóico Médio do Estado de Goiás. Anais da Academia Brasileira de Ciências, 58:611.

Rezende, M.F. \& Bergamaschi, S. 2008. Estratigrafia química no intervalo Praguiano-Emsiano (Formação Ponta Grossa), no bordo leste da Bacia do Paraná. In: CONGRESSO BRASILEIRO DE GEOLOGIA, 43, 2006. Coletânea de trabalhos completos, Salvador, SBG, p. 835-838.

Rodrigues, M.A.C.; Pereira, E. \& Bergamaschi, S. 1988. Análise faciológica da seqüência superior da Formação Furnas: identificação de depósitos deltáicos e de ilhas de barreira nas regiões de Ponta Gorossa e Tibagi, PR. Anais da Academia Brasileira de Ciências, 60:497.

Rodrigues, M.A.C.; Pereira, E. \& Bergamaschi, S. 1989. Ocorrência de Psilophytales na Formação Furnas, borda leste da Bacia do Paraná. Boletim do IG-USP, Publicação Especial, 7:35-43.

Rubinstein, C.; Melo, J.H.G. \& Steemans, P. 2005. Lochkovian (earliest Devonian) miospores from the Solimões Basin, northwestern Brazil. Review of Palaeobotany and Palynology, 133:91-113.

Rubinstein, C. 2008. Lochkovian (Early Devonian) acritarchs and prasinophytes from the Solimões Basin, northwestern Brazil. Neues Jahrbuch für Geologie und Paläontologie, Abhandlungen, 249:167-184. 
Sanford, R.M. \& Lange, F.W. 1960. Basin study approach to oil evaluation of Paraná miogeosyncline, South Brasil. Bulletin of the American Association of Petroleum Geologists, 44:13161370 .

Tamura, T. \& Masuda, F. 2005. Bed thickness characteristics of inner shelf storm deposits associated with a transgressive to regressive Holocene wave-dominated shelf, Sendai coastal plain, Japan. Sedimentology, 52:1375-1395.

Zabini, C.; Bosetti, E.P. \& Holz, M. 2010. Taphonomy and taphofacies analysis of lingulid brachiopods from Devonian sequences of the Paraná Basin, Brazil. Palaeogeography, Palaeoclimatology, Palaeoecology, 292:44-56.

Zalan, P.V.; Wolff, S.; Conceição, J.C.J.; Vieira, I.S.; Astolfi, M.A.M.; Appi, V.T. \& Zanotto, O.A. 1987. A divisão tripartite do Siluriano da Bacia do Paraná. Revista Brasileira de Geociências, 17:242-252.

Received in February, 2010; accepted in May, 2010.

Appendix 1. List of taxa mentioned or discussed in text and/or figures.

\section{Spores}

cf. Acinosporites sp.

Ambitisporites avitus Hoffmeister, 1959

Aneurospora geikiei Wellman \& Richardson, 1996

Apiculiretusispora brandtii Streel, 1964

Apiculiretusispora plicata (Allen) Streel, 1967

Apiculiretusispora spp.

Archaeozonotriletes chulus (Cramer) Richardson \& Lister, 1969

Artemopyra recticosta Breuer et al., 2007

Artemopyra cf. recticosta Breuer et al., 2007

Brochotriletes foveolatus (Naumova) McGregor, 1973

cf. Brochotriletes foveolatus (Naumova) McGregor, 1973

Chelinospora retorrida Turnau, 1986

Cirratriradiates diaphanus Steemans, 1989

Cymbosporites asymmetricus Breuer et al., 2007

cf. Cymbosporites asymmetricus Breuer et al., 2007

Cymbosporites spp.

Dibolisporites echinaceus (Eisenack) Richardson, 1965

Dibolisporites eifeliensis (Lanninger) McGregor, 1973

Dibolisporites cf. eifeliensis (Lanninger) McGregor, 1973

Dibolisporites spp.

Dictyotriletes emsiensis (Allen) McGregor, 1973

Dictyotriletes aff. emsiensis sensu Le Hérisse, 1983

Dictyotriletes emsiensis morphon sensu Rubinstein et al., 2005.

Dictyotriletes granulatus Steemans, 1989

Dictyotriletes subgranifer McGregor, 1973

Dictyotriletes sp. cf. D. richardsonii Steemans, 1989

Dictyotriletes spp. (D. emsiensis ?)

Emphanisporites rotatus McGregor, 1973

?Knoxisporites riondae Cramer \& Díez, 1975

Retusotriletes maculatus McGregor \& Camfield, 1976

Retusotriletes sp.

Synorisporites papillensis McGregor, 1973

Synorisporites verrucatus Richardson \& Lister, 1969

Tetrahedraletes medinensis Strother \& Traverse emend. Wellman \& Richardson, 1993

Zonotriletes sp.

\section{Acritarchs and algae}

Anthatractus insolitus Deunff, 1954

Baltisphaeridium paraguaferum Cramer, 1964

Deunffia sp.

Diexallophasis remota (Deunff) Playford, 1977

Gorgonisphaeridium sp.

Leiosphaerida spp.

Polyedryxium decorum Deunff, 1955

Quadrisporites granulatus Cramer \& Cramer, 1972

Quadrisporites horridus (Hennelly) Potonié \& Lele, 1961

Schizocystia sp.

Tasmanites sp.

Tyligmasoma spp.

Veryhachium rabiosum Cramer, 1964

Veryhachium trispiniflatum Cramer, 1964

Veryhachium spp. 


\section{Chitinozoans}

Ancyrochitina pachycerata Gaugris \& Grahn, 2006

Ancyrochitina n.sp. C sensu Gaugris \& Grahn, 2006 = Ancyrochitina aff. A. pachycerata

Ancyrochitina sp. B sensu Grahn, 2000

Ancyrochitina varispinosa? (Lange, 1967)

Ancyrochitina spp.

Angochitina daemoni Grahn, 2000

Ramochitina magnífica Lange, 1967

Ramochitina ramosi Sommer \& Boekel, 1964 